\title{
Thermal Dehydrogenation Characteristics of Li-Sr-Al-N-H Hydrogen Storage System
}

\author{
Yue Zhanga, Tingzhi Sia, Yongtao Li $i^{a}$, Dongming Liu ${ }^{a}$ * \\ ${ }^{a}$ School of Materials Science and Engineering, Anhui University of Technology, Maanshan, Anhui \\ 243002, P. R. China
}

Received: August 04, 2017; Revised: October 20, 2017; Accepted: November 19, 2017

\begin{abstract}
Thermolysis behavior of the Li-Sr-Al-N-H hydrogen storage system prepared by ball milling of $\mathrm{Sr}_{2} \mathrm{AlH}_{7}+\mathrm{LiNH}_{2}$ mixture was investigated in this paper. The results show that thermal decomposition of the Li-Sr-Al-N-H system proceeds mainly in two steps with only hydrogen desorption. The thermal stability of this system is lowered as compared to the individual starting material, resulting in the hydrogen desorption initiating from about $125^{\circ} \mathrm{C}$. In addition, about 0.91 and $1.53 \mathrm{wt} . \%$ of hydrogen can be isothermally desorbed within $180 \mathrm{~min}$ at 180 and $330^{\circ} \mathrm{C}$, respectively. The decreased thermal stability of the Li-Sr-Al-N-H system might be attributed to the chemical reactions between the starting materials during the heating process with the formation of $\mathrm{LiSrH}_{3}$ and $\mathrm{N}$-containing amorphous phases.
\end{abstract}

Keywords: Hydrogen storage material, Metal-N-H system, Dehydrogenation property, Reaction mechanism

\section{Introduction}

Hydrogen has been regarded as a promising alternative for the conventional fossil energy sources due to its high calorific value, low environmental impact and abundant reserves. For the wide applications of hydrogen energy, an effective and safe storage technology must be developed. Compared to the gas- and/or liquid-state hydrogen storage, the storage of hydrogen in solid state based on the physical or chemical interaction between hydrogen and hydrogen storage materials usually has a higher hydrogen density. Among the developed hydrogen storage materials, the metal aluminum hydrides such as $\mathrm{LiAlH}_{4}, \mathrm{NaAlH}_{4}$ and $\mathrm{Mg}\left(\mathrm{AlH}_{4}\right)_{2}$ are some of the most promising candidates for the on-board hydrogen storage owing to their high hydrogen capacity $^{1-6}$. For example, Liu et al. found that the Ti-doped $\mathrm{LiAlH}_{4}$ can release $7 \mathrm{wt} . \%$ of hydrogen commencing at temperature as low as $80^{\circ} \mathrm{C}$, and that the dehydrogenated product can be re-hydrogenated almost completely under 100 bar of hydrogen and room temperature by employing liquid $\mathrm{Me}_{2} \mathrm{O}$ as a solvent ${ }^{3}$. In 2002, an alkaline-earth metal aluminum hydride with a special crystal structure, $\mathrm{Sr}_{2} \mathrm{AlH}_{7}$, was obtained by the hydrogenation of Zintl compound $\mathrm{SrAl}_{2}^{7}$. Further studies indicate that it can also be synthesized by the reaction of $\mathrm{SrH}_{2}, \mathrm{Al}$ and hydrogen ${ }^{8,9}$.

In addition, growing attention has also been paid to the metal-N-H systems as hydrogen storage materials in the last decade ${ }^{10-28}$. Chen et al. first reported that the binary $\mathrm{LiNH}_{2}-$ LiH (1:2) system exhibits reversible de-/hydrogenation reactions in a two-step process, which can be expressed as ${ }^{10}$.

$\mathrm{LiNH}_{2}+2 \mathrm{LiH} \leftrightarrow \mathrm{Li}_{2} \mathrm{NH}+\mathrm{LiH}+\mathrm{H}_{2} \leftrightarrow \mathrm{Li}_{3} \mathrm{~N}+2 \mathrm{H}_{2}$

*e-mail:1dm_ahut@163.com
This Li-N-H system has a hydrogen storage capacity as high as $10 \mathrm{wt} . \%$. Unfortunately, its dehydrogenation temperature is too high for practical applications. To destabilize the Li$\mathrm{N}-\mathrm{H}$ system, $\mathrm{Li}$ was partially substituted by $\mathrm{Mg}$ or $\mathrm{Ca}$, and the ternary $\mathrm{Li}-\mathrm{Mg}-\mathrm{N}-\mathrm{H}^{11-17}$ and $\mathrm{Li}-\mathrm{Ca}-\mathrm{N}-\mathrm{H}^{18-20}$ hydrogen storage systems were developed. Moreover, the combined alkali metal aluminum hydride-metal amide systems such as $\mathrm{LiAlH}_{4}-\mathrm{LiNH}_{2}{ }_{2}^{21-24}, \mathrm{Li}_{3} \mathrm{AlH}_{6}-\mathrm{LiNH}_{2}{ }^{25,26}, \mathrm{LiAlH}_{4}-\mathrm{Mg}\left(\mathrm{NH}_{2}\right)_{2}{ }^{27}$ and $\mathrm{Na}_{2} \mathrm{LiAlH}_{6}-\mathrm{Mg}\left(\mathrm{NH}_{2}\right)_{2}{ }^{28}$ were intensively studied. However, the metal-N-H systems consisting of alkaline-earth metal aluminum hydride and metal amide were rarely reported. In the present work, the multinary Li-Sr-Al-N-H system was constructed by combining $\mathrm{Sr}_{2} \mathrm{AlH}_{7}$ with $\mathrm{LiNH}_{2}$ in a molar ratio of 1:1, and its thermal decomposition properties as well as the chemical reactions involved in the heating process were investigated.

\section{Experimental}

\subsection{Sample preparation}

The starting material $\mathrm{LiNH}_{2}(95 \%$, J\&K Chemical) was purchased and used as-received. The hydride $\mathrm{Sr}_{2} \mathrm{AlH}_{7}$ was prepared by the same method reported in our previous paper ${ }^{29}$. Rietveld analysis (see Table 1) shows that the $\mathrm{Sr}_{2} \mathrm{AlH}_{7}$ hydride is composed of $85 \mathrm{wt} . \% \mathrm{Sr}_{2} \mathrm{AlH}_{7}, 13 \mathrm{wt} . \% \mathrm{SrH}_{2}, 1 \mathrm{wt} . \% \mathrm{Al}$ and 1 wt.\% SrO. The Li-Sr-Al-N-H system was prepared by ball milling the mixture of $\mathrm{Sr}_{2} \mathrm{AlH}_{7}$ and $\mathrm{LiNH}_{2}$ powders in a molar ratio of $1: 1$. The milling operation was performed under $0.5 \mathrm{MPa}$ of hydrogen atmosphere at a rotation speed of $400 \mathrm{rpm}$ for $2 \mathrm{~h}$ by using a QM-1SP2 planetary mill. Stainless steel vials ( $250 \mathrm{~mL}$ in volume) and balls $(10 \mathrm{~mm}$ in diameter) were used. The ball to powder weight ratio 
was 20:1. To prevent the sample from air-exposure, all the sample handling was carried out in an Ar-filled glove box equipped with a purification system, in which the typical $\mathrm{O}_{2} / \mathrm{H}_{2} \mathrm{O}$ levels were below $1 \mathrm{ppm}$.

Table 1. Structural parameters and phase abundance of the $\mathrm{Sr}_{2} \mathrm{AlH}_{7}$ hydride refined by Rietveld analysis.

\begin{tabular}{ccccc}
\hline \multirow{2}{*}{ Phase } & $\begin{array}{c}\text { Space } \\
\text { Group }\end{array}$ & \multicolumn{2}{c}{ Lattice Parameters } & \multirow{2}{*}{$\begin{array}{c}\text { Abundance } \\
\text { (wt.\%) }\end{array}$} \\
\cline { 3 - 4 } $\mathrm{Sr}_{2} \mathrm{AlH}_{7}$ & $I 2 / a$ & $\begin{array}{c}12.5812 \\
(6)\end{array}$ & $\begin{array}{c}7.9992 \\
(4)\end{array}$ & 85 \\
$\mathrm{SrH}_{2}$ & Pnma & $\begin{array}{c}6.3881 \\
(5)\end{array}$ & $\begin{array}{c}7.3277 \\
(8)\end{array}$ & 13 \\
$\mathrm{Al}$ & $F m-3 m$ & $\begin{array}{c}4.0518 \\
(7)\end{array}$ & 1 \\
$\mathrm{SrO}$ & $F m-3 m$ & $\begin{array}{c}5.1594 \\
(5)\end{array}$ & 1 \\
\hline
\end{tabular}

\subsection{Determination of thermal decomposition properties}

Thermolysis process of the as-milled $\mathrm{Sr}_{2} \mathrm{AlH}_{7}+\mathrm{LiNH}_{2}$ mixture was monitored using a simultaneous thermal analyzer (NETZSCH STA 449) equipped with a quadrupole mass spectrometer (QMS 403C) in the temperature range of 25-500 ${ }^{\circ} \mathrm{C}$. Differential thermal analysis (DTA), thermogravimetry (TG) and mass spectrometry (MS) measurements were carried out under argon flow $(30 \mathrm{ml} / \mathrm{min})$ at a heating rate of $2{ }^{\circ} \mathrm{C} /$ min. In addition, isothermal dehydrogenation for the Li-Sr-Al$\mathrm{N}-\mathrm{H}$ system was measured based on the volumetric method by using a carefully calibrated Sieverts-type apparatus. Two separate experiments with two separate samples were carried out. One sample was exposed to $180{ }^{\circ} \mathrm{C}$ and the other was exposed to $330^{\circ} \mathrm{C}$. Prior to hydrogen desorption, the testing system of the apparatus was evacuated.

\subsection{Phase composition characterization}

To analyze the phase compositions of the $\mathrm{Sr}_{2} \mathrm{AlH}_{7}+$ $\mathrm{LiNH}_{2}$ mixture as-milled and after heat treatment at different temperatures, X-ray diffraction (XRD) measurements were performed using a Rigaku D/Max 2500VL/PC diffractometer with $\mathrm{Cu} \mathrm{K \alpha}$ radiation at $50 \mathrm{kV}$ and $200 \mathrm{~mA}$. The XRD samples were loaded and sealed in an air-tight holder that can keep the sample under argon atmosphere during the measurement. In addition, the XRD pattern of the heattreated product was analyzed with the Rietveld refinement program RIETAN-2000 ${ }^{30}$.

\section{Results and Discussion}

\subsection{Thermal decomposition properties}

Fig. 1 gives the DTA/TG curves for the as-milled $\mathrm{Sr}_{2} \mathrm{AlH}_{7}+\mathrm{LiNH}_{2}$ mixture during the heating process at a rate of $2{ }^{\circ} \mathrm{C} / \mathrm{min}$. It is observed that there are two prominent DTA endothermic peaks centered at about 190 and 355 ${ }^{\circ} \mathrm{C}$, respectively ( see Fig. 1a), indicating that there exists two obvious endothermic events in the temperature range of $25-500{ }^{\circ} \mathrm{C}$. The TG curve (see Fig. 1b) shows that the thermal decomposition process of the Li-Sr-Al-N-H system was accompanied by obvious mass loss, and that the total mass loss is about 1.97 wt.\% up to $500{ }^{\circ} \mathrm{C}$. Furthermore, Fig. 2 presents the simultaneous MS analysis of the released gas during the heating process. It is clear that there are two peaks originating from $\mathrm{H}_{2}$ desorption, and that $\mathrm{NH}_{3}$ release was not detected from the Li-Sr-Al-N-H system. These two $\mathrm{H}_{2}$-MS peaks correspond to the two endothermic peaks observed in Fig. 1a. On the basis of the above results, it can be concluded that the thermal decomposition of the $\mathrm{Sr}_{2} \mathrm{AlH}_{7}$ $+\mathrm{LiNH}_{2}$ mixture ball milled for $2 \mathrm{~h}$ is a two-step process with hydrogen desorption only. The first step occurs in the temperature range of $125-270{ }^{\circ} \mathrm{C}$, and releases about 1.03 wt.\% of hydrogen; and the second one starts following the first step and ends at about $400{ }^{\circ} \mathrm{C}$, with about 0.94 wt.\% of hydrogen released.

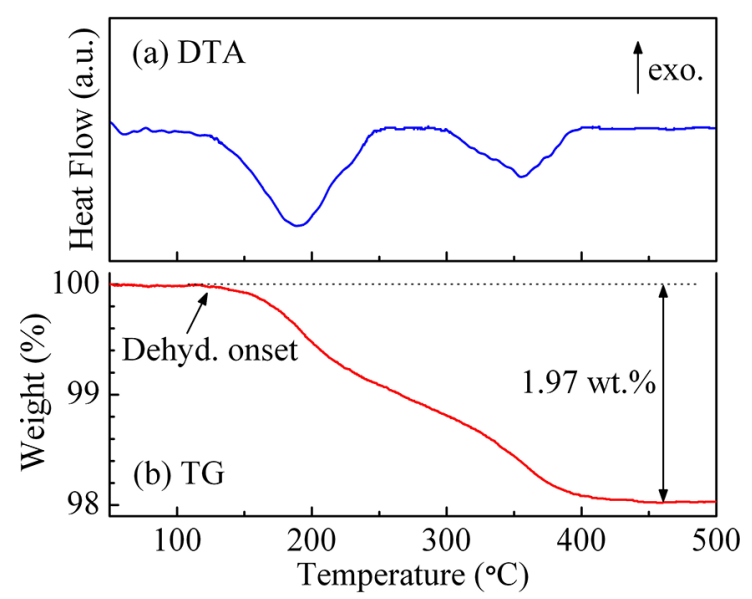

Figure 1. DTA/TG curves of the as-milled $\mathrm{Sr}_{2} \mathrm{AlH}_{7}+\mathrm{LiNH}_{2}$ mixture.

According to the DTA/TG-MS results, two different temperatures of 180 and $330^{\circ} \mathrm{C}$ were selected to further investigate the isothermal dehydrogenation properties of the Li-Sr-Al-N-H system. As shown in Fig. 3, about 0.91 wt.\% of hydrogen can be desorbed within $180 \mathrm{~min}$ at 180 ${ }^{\circ} \mathrm{C}$. When the Li-Sr-Al-N-H system was exposed to $330^{\circ} \mathrm{C}$, the hydrogen amount desorbed within 180 min increases to about 1.53 wt.\%. In contrast, the individual $\mathrm{Sr}_{2} \mathrm{AlH}_{7}$ ball milled for $2 \mathrm{~h}$ (in the absence of $\mathrm{LiNH}_{2}$ ) did not release any noticeable amount of hydrogen at the temperature below 180 ${ }^{\circ} \mathrm{C}$. In addition, the decomposition reaction of $\mathrm{LiNH}_{2}$ has been found to happen only at the temperature higher than $220{ }^{\circ} \mathrm{C}^{11,21,31}$. The results indicate that $\mathrm{Sr}_{2} \mathrm{AlH}_{7}$ and $\mathrm{LiNH}_{2}$ can be chemically destabilized by combination to each other. Similar to the Li-Mg-N-H ${ }^{11-16}$ and Li-Al-N-H ${ }^{21-26}$ systems, the chemical reactions between $\mathrm{Sr}_{2} \mathrm{AlH}_{7}$ and $\mathrm{LiNH}_{2}$ rather 


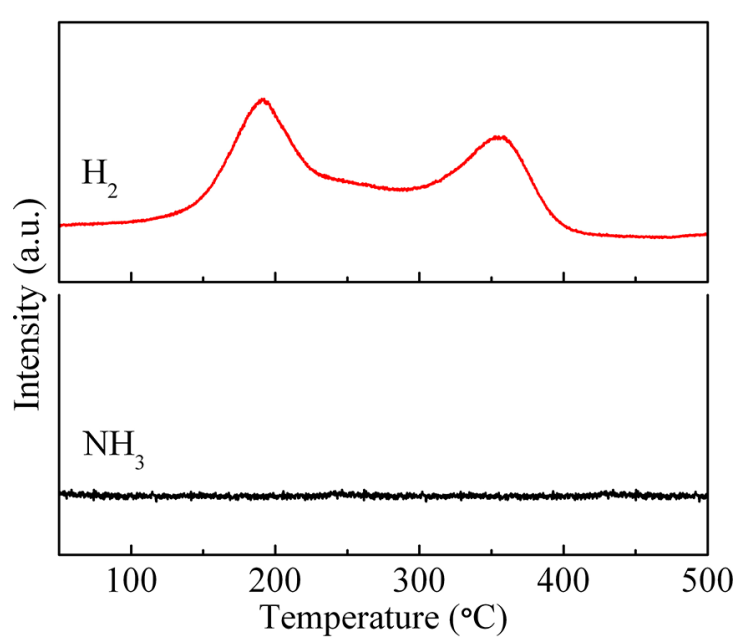

Figure 2. $\mathrm{H}_{2}$ - and $\mathrm{NH}_{3}-\mathrm{MS}$ curves of the as-milled $\mathrm{Sr}_{2} \mathrm{AlH}_{7}+$ $\mathrm{LiNH}_{2}$ mixture

than the catalytical role may be the reason for the decreased dehydrogenation temperature in the present case. The dehydrogenation reactions involved in the Li-Sr-Al-N-H system will be discussed below.

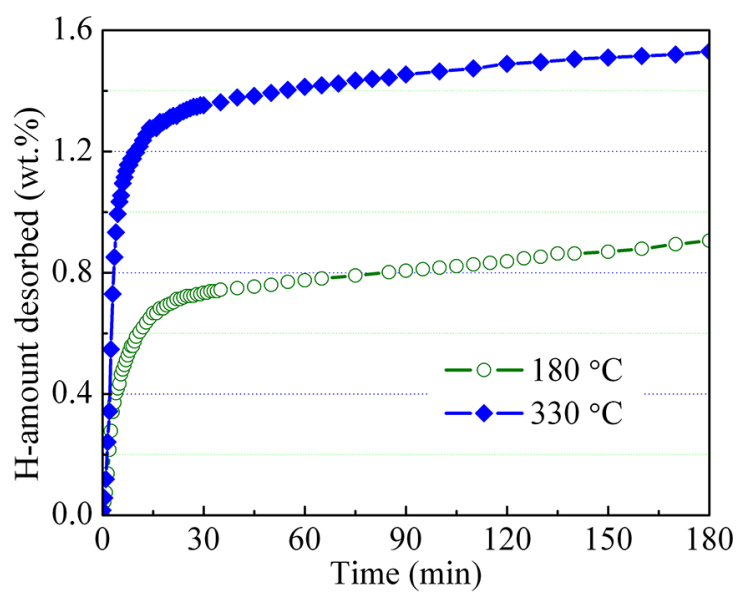

Figure 3. Time dependences of dehydrogenation for the as-milled $\mathrm{Sr}_{2} \mathrm{AlH}_{7}+\mathrm{LiNH}_{2}$ mixture at 180 and $330^{\circ} \mathrm{C}$, respectively

\subsection{Phase compositions}

Fig. 4 displays the XRD patterns of the $\mathrm{Sr}_{2} \mathrm{AlH}_{7}+\mathrm{LiNH}_{2}$ mixture after ball milling, as well as after heat treatment at different temperatures. It can be seen from Fig. 4a that the as-milled $\mathrm{Sr}_{2} \mathrm{AlH}_{7}+\mathrm{LiNH}_{2}$ mixture is composed of the starting materials, implying that no obvious reactions occurred during ball milling for $2 \mathrm{~h}$. When the as-milled $\mathrm{Sr}_{2} \mathrm{AlH}_{7}+\mathrm{LiNH}_{2}$ mixture was heated to $180^{\circ} \mathrm{C}$, as indicated in Fig. $4 \mathrm{~b}$, the characteristic diffraction peaks from $\mathrm{Sr}_{2} \mathrm{AlH}_{7}$ and $\mathrm{LiNH}_{2}$ are still dominant in the XRD pattern. However, a new diffraction peak $\left(2 \theta=32.8^{\circ}\right)$ assigned to $\mathrm{LiSrH}_{3}$ appears in Fig. 4b, indicating the occurrence of chemical reactions in the Li-Sr-Al-N-H system. Increasing the heat treatment temperature to $330^{\circ} \mathrm{C}$, as shown in Fig. $4 \mathrm{c}$, the diffraction peaks from $\mathrm{LiSrH}_{3}$ are enhanced drastically, while those from $\mathrm{Sr}_{2} \mathrm{AlH}_{7}$ are weakened. In addition, $\mathrm{SrH}_{2}$ can be observed, together with a small amount of $\mathrm{Al}$ and $\mathrm{SrO}$ in the product dehydrogenated at $330{ }^{\circ} \mathrm{C}$. However, there is no diffraction peak that can be unambiguously ascribed to any $\mathrm{N}$-containing phases.

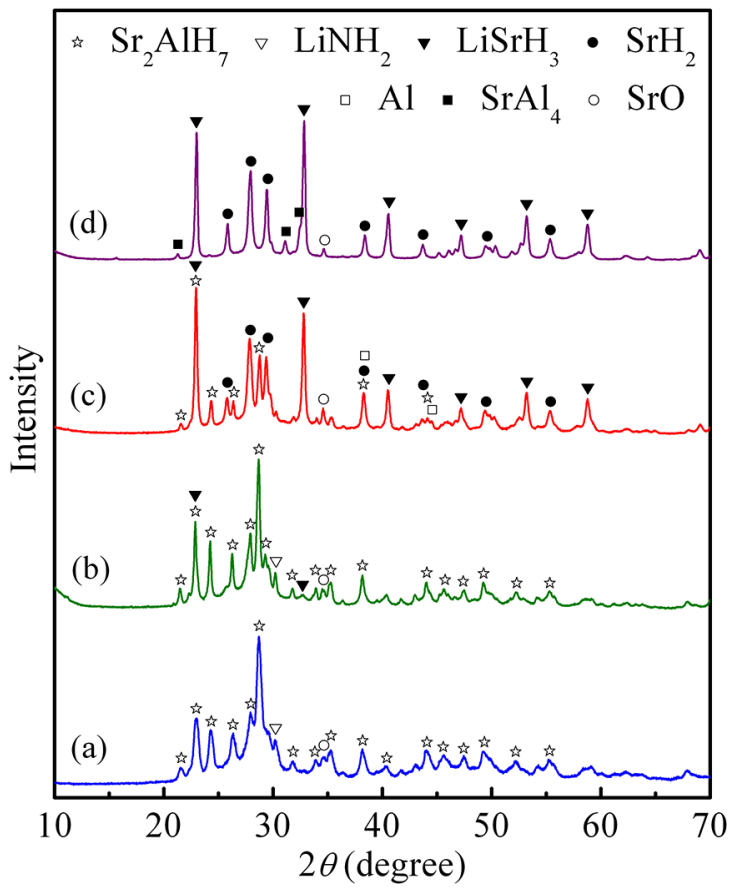

Figure 4. $\mathrm{XRD}$ patterns of the $\mathrm{Sr}_{2} \mathrm{AlH}_{7}+\mathrm{LiNH}_{2}$ mixture as-milled (a) and after heat treatment at 180 (b), 330 (c) and $500{ }^{\circ} \mathrm{C}$ (d), respectively.

To further confirm the presence of these crystalline phases, the XRD pattern in Fig. 4c was refined by Rietveld method. It can be seen from Fig. 5 that the diffraction pattern calculated from the structure models of the above five phases ( $\mathrm{LiSrH}_{3}, \mathrm{SrH}_{2}, \mathrm{Sr}_{2} \mathrm{AlH}_{7}, \mathrm{Al}$ and $\mathrm{SrO}$ ) is in good agreement with that measured. Because no $\mathrm{NH}_{3}$ was released during the heating process, it is reasonable to consider that the $\mathrm{N}$-containing phases exist in the predominantly amorphous form. Similar phenomena of the formation of amorphous phases were also reported in other combined systems of metal aluminum hydride and metal amide ${ }^{21,27,32}$. As shown in Fig. 4 d, the product dehydrogenated at $500^{\circ} \mathrm{C}$ is composed of $\mathrm{LiSrH}_{3}, \mathrm{SrH}_{2}, \mathrm{SrAl}_{4}$ and $\mathrm{SrO}$. Again, the N-containing crystalline phases cannot be observed from the XRD pattern.

\subsection{Dehydrogenation reactions}

As indicated in Section 3.1, thermal decomposition of the $\mathrm{Sr}_{2} \mathrm{AlH}_{7}-\mathrm{LiNH}_{2}(1: 1)$ system is a two-step dehydrogenation process without $\mathrm{NH}_{3}$ emission. Based on the above phase composition analysis, the dehydrogenation reactions during the heating process can be deduced. Since $\mathrm{SrH}_{2}$ can react with $\mathrm{LiNH}_{2}$ to form $\mathrm{LiSrH}_{3}$ and $\mathrm{SrNH}$ at temperatures up to $180^{\circ} \mathrm{C}$ according to reaction $(2)^{33}$ and that $13 \mathrm{wt} . \% \mathrm{SrH}_{2}$ is present in 


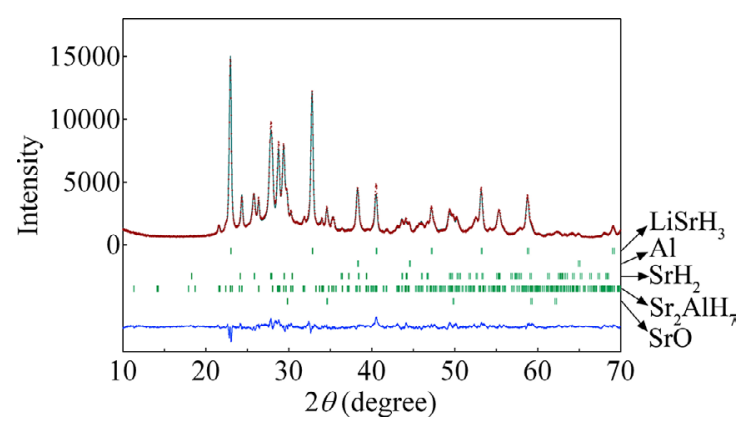

Figure 5. Rietveld refinement of the XRD pattern for the as-milled $\mathrm{Sr}_{2} \mathrm{AlH}_{7}+\mathrm{LiNH}_{2}$ mixture dehydrogenated at $330^{\circ} \mathrm{C}$. The vertical bars (from above) indicate the positions of Bragg diffraction for $\mathrm{LiSrH}_{3}, \mathrm{Al}, \mathrm{SrH}_{2}, \mathrm{Sr}_{2} \mathrm{AlH}_{7}$ and $\mathrm{SrO}$, respectively. (The reliability factors for refinement are $R_{\mathrm{wp}}=5.81 \%, R_{\mathrm{p}}=4.59 \%$ and $S=2.42$ )

the starting material $\mathrm{Sr}_{2} \mathrm{AlH}_{7}$, the first dehydrogenation step for the Li-Sr-Al-N-H system was thought to be originated from the reaction between $\mathrm{SrH}_{2}$ and $\mathrm{LiNH}_{2}$.

$$
2 \mathrm{SrH}_{2}+\mathrm{LiNH}_{2} \rightarrow \mathrm{LiSrH}_{3}+\mathrm{SrNH}+\mathrm{H}_{2}
$$

Based on reaction (2), the hydrogen amount desorbed from Li-Sr-Al-N-H system can be calculated to be about $0.13 \mathrm{wt} . \%$. This value is much lower than that experimentally obtained $(\sim 0.91$ wt.\%) as shown in Fig. 3, indicating that a certain amount of $\mathrm{Sr}_{2} \mathrm{AlH}_{7}$ must also react with $\mathrm{LiNH}_{2}$ to release hydrogen at $180{ }^{\circ} \mathrm{C}$. Thus, the dehydrogenation reaction between $\mathrm{SrH}_{2}$ and $\mathrm{LiNH}_{2}$, as well as that between part $\mathrm{Sr}_{2} \mathrm{AlH}_{7}$ and $\mathrm{LiNH}_{2}$ both contribute to the first dehydrogenation step as observed in Figs. 1 and 2.

With the increase of decomposition temperature, $\mathrm{LiNH}_{2}$ reacted with remaining $\mathrm{Sr}_{2} \mathrm{AlH}_{7}$ completely, resulting in the formation of $\mathrm{LiSrH}_{3}, \mathrm{~N}$-containing amorphous phases, $\mathrm{SrH}_{2}$ and $\mathrm{Al}$ as shown in Fig. 4c. Meanwhile, $\mathrm{SrH}_{2}$ reacted with $\mathrm{Al}$ to directly form $\mathrm{SrAl}_{4}$ and the residual $\mathrm{Sr}_{2} \mathrm{AlH}_{7}$ decomposed into $\mathrm{SrH}_{2}$ and $\mathrm{SrAl}_{4}$ based on the following reaction':

$$
4 \mathrm{Sr}_{2} \mathrm{AlH}_{7} \rightarrow 7 \mathrm{SrH}_{2}+\mathrm{SrAl}_{4}+7 \mathrm{H}_{2}
$$

These reactions contribute to the second dehydrogenation peak shown in Figs. 1 and 2. According to the results and discussion above, the overall reaction taken place during the heating process up to $500{ }^{\circ} \mathrm{C}$ for the $\mathrm{Sr}_{2} \mathrm{AlH}_{7}-\mathrm{LiNH}_{2}(1: 1)$ system can be described qualitatively as:

$$
\begin{aligned}
& \mathrm{Sr}_{2} \mathrm{AlH}_{7}+\mathrm{LiNH}_{2} \rightarrow \mathrm{LiSrH}_{3}+\mathrm{SrH}_{2}+\mathrm{SrAl}_{4}+(4) \\
& \mathrm{N}_{-} \text {containing amorphus phases }+\mathrm{H}_{2}
\end{aligned}
$$

\section{Conclusions}

In this paper, the thermal decomposition properties and chemical reactions involved in the heating process for the combined $\mathrm{Sr}_{2} \mathrm{AlH}_{7}-\mathrm{LiNH}_{2}$ (1:1) hydrogen storage system were studied. It was found that thermal decomposition of the Li-Sr-Al-N-H system is a two-step dehydrogenation process without detectable $\mathrm{NH}_{3}$ emission. This system begins to release hydrogen at about $125^{\circ} \mathrm{C}$, and can isothermally desorb about 0.91 and 1.53 wt.\% of hydrogen within 180 min at 180 and $330{ }^{\circ} \mathrm{C}$, respectively. The chemical reactions between the starting materials during the heating process to form $\mathrm{LiSrH}_{3}$ and $\mathrm{N}$-containing amorphous phases may be the reason for the decreased dehydrogenation temperature. Further investigations on the effect of composition change on the decomposition behaviors might be of significance for the improvement of the hydrogen storage properties of the $\mathrm{Sr}_{2} \mathrm{AlH}_{7}-\mathrm{LiNH}_{2}$ system.

\section{Acknowledgments}

This work was financially supported by the National Natural Science Foundation of China (No. 51371008) and the Key Project of Outstanding Young Talents in Universities of Anhui Province (No. gxyqZD2016067).

\section{References}

1. Jain IP, Jain P, Jain A. Novel hydrogen storage materials: A review of lightweight complex hydrides. Journal of Alloys and Compounds. 2010;503(2):303-339.

2. Durbin DJ, Malardier-Jugroot C. Review of hydrogen storage techniques for on board vehicle applications. International Journal of Hydrogen Energy. 2013;38(34):14595-14617.

3. Liu X, McGrady GS, Langmi HW, Jensen CM. Facial Cycling of Ti-Doped $\mathrm{LiAlH}_{4}$ for High Performance Hydrogen Storage. Journal of the American Chemical Society. 2009;131(14):50325033.

4. Liu Y, Liang C, Zhou H, Gao M, Pan H, Wang Q. A novel catalyst precursor $\mathrm{K}_{2} \mathrm{TiF}_{6}$ with remarkable synergetic effects of $\mathrm{K}$, Ti and $\mathrm{F}$ together on reversible hydrogen storage of $\mathrm{NaAlH}_{4}$. Chemical Communications. 2011;47(6):1740-1742.

5. Zhang T, Isobe S, Wang Y, Liu C, Hashimoto N, Takahashi K. Enhanced hydrogen desorption properties of $\mathrm{LiAlH}_{4}$ by doping lithium metatitanate. Physical Chemistry Chemical Physics. 2016;18(39):27623-27629.

6. Pang Y, Li Q. Insight into the kinetic mechanism of the firststep dehydrogenation of $\mathrm{Mg}\left(\mathrm{AlH}_{4}\right)_{2}$. Scripta Materialia. 2017;130:223-228.

7. Zhang QA, Nakamura Y, Oikawa KI, Kamiyama T, Akiba E. Synthesis and Crystal Structure of $\mathrm{Sr}_{2} \mathrm{AlH}_{7}$ : a New Structural Type of Alkaline Earth Aluminum Hydride. Inorganic Chemistry. 2002;41(25):6547-6549.

8. Zhang QA, Akiba E. Synthesis of $\mathrm{Sr}_{2} \mathrm{AlH}_{7}$ by ball milling followed by hydrogenation. Journal of Alloys and Compounds. 2005;394(1-2):308-311.

9. Zhang QA, Akiba E. Reactions in the $\mathrm{SrH}_{2}-\mathrm{Al}-\mathrm{H}_{2}$ system. Journal of Alloys and Compounds. 2008;460(1-2):272-275.

10. Chen P, Xiong Z, Luo J, Lin J, Tan KL. Interaction of hydrogen with metal nitrides and imides. Nature. 2002;420(6913):302304. 
11. Nakamori Y, Kitahara G, Miwa K, Ohba N, Noritake T, Towata $\mathrm{S}$, et al. Hydrogen storage properties of $\mathrm{Li}-\mathrm{Mg}-\mathrm{N}-\mathrm{H}$ systems. Journal of Alloys and Compounds. 2005;404-406:396-398.

12. Liu Y, Zhong K, Gao M, Wang J, Pan H, Wang Q. Hydrogen storage in a $\mathrm{LiNH}_{2}-\mathrm{MgH}_{2}(1: 1)$ system. Chemistry of Materials. 2008;20(10):3521-3527.

13. Markmaitree T, Shaw LL. Synthesis and hydriding properties of $\mathrm{Li}_{2} \mathrm{Mg}(\mathrm{NH})_{2}$. Journal of Power Sources. 2010;195(7):19841991 .

14. Cao H, Wang H, He T, Wu G, Xiong Z, Qiu J, et al. Improved kinetics of the $\mathrm{Mg}\left(\mathrm{NH}_{2}\right)_{2}-2 \mathrm{LiH}$ system by addition of lithium halides. RSC Advances. 2014;4(61):32555-32561.

15. Paik B, Li HW, Wang J, Akiba E. A Li-Mg-N-H composite as $\mathrm{H}_{2}$ storage material: a case study with $\mathrm{Mg}\left(\mathrm{NH}_{2}\right)_{2}-4 \mathrm{LiH}-\mathrm{LiNH}_{2}$. Chemical Communications. 2015;51(49):10018-10021.

16. Jung JH, Kim D, Hwang J, Lee YL, Ihm J. Theoretical study on the hydrogen storage mechanism of the $\mathrm{Li}-\mathrm{Mg}-\mathrm{N}-\mathrm{H}$ system. International Journal of Hydrogen Energy. 2016;41(39):1750617510.

17. Zhang B, Wu Y. Recent advances in improving performances of the lightweight complex hydrides Li-Mg-N-H system. Progress in Natural Science-Materials International. 2017;27(1):21-33.

18. Tokoyoda K, Hino S, Ichikawa T, Okamoto K, Fujii H. Hydrogen desorption/absorption properties of Li-Ca-N-H system. Journal of Alloys and Compounds. 2007;439(1-2):337-341.

19. Wu H. Structure of Ternary Imide $\mathrm{Li}_{2} \mathrm{Ca}(\mathrm{NH})_{2}$ and Hydrogen Storage Mechanisms in Amide-Hydride System. Journal of the American Chemical Society. 2008;130(20):6515-6522.

20. Chu H, Xiong Z, Wu G, He T, Wu C, Chen P. Hydrogen storage properties of $\mathrm{Li}-\mathrm{Ca}-\mathrm{N}-\mathrm{H}$ system with different molar ratios of $\mathrm{LiNH}_{2} / \mathrm{CaH}_{2}$. International Journal of Hydrogen Energy. 2010;35(15):8317-8321.

21. Xiong $\mathrm{Z}, \mathrm{Wu} \mathrm{G}, \mathrm{Hu} \mathrm{J}$, Chen P. Investigation on chemical reaction between $\mathrm{LiAlH}_{4}$ and $\mathrm{LiNH}_{2}$. Journal of Power Sources. 2006;159(1):167-170.

22. Chen R, Wang X, Chen L, Li S, Ge H, Lei Y, et al. An investigation on the reaction pathway between $\mathrm{LiAlH}_{4}$ and $\mathrm{LiNH}_{2}$ via gaseous ammonia. Journal of Alloys and Compounds. 2010;495(1):17-22.
23. Dolotko O, Kobayashi T, Wiench JW, Pruski M, Pecharsky $\mathrm{V}$. Investigation of the thermochemical transformations in the $\mathrm{LiAlH}_{4}-\mathrm{LiNH}_{2}$ system. International Journal of Hydrogen Energy. 2011;36(17):10626-10634.

24. Jepsen LH, Ravnsbæk DB, Grundlach C, Besenbacher F, Skibsted $\mathrm{J}$, Jensen TR. A novel intermediate in the $\mathrm{LiAlH}_{4}-\mathrm{LiNH}_{2}$ hydrogen storage system. Dalton Transactions. 2014;43(8):3095-3103.

25. Lu J, Fang ZZ, Sohn HY. A New Li-Al-N-H System for Reversible Hydrogen Storage. The Journal of Physical Chemistry B. 2006;110(29):14236-14239.

26. Yang J, Wang X, Mao J, Chen L, Pan H, Li S, et al. Investigation on reversible hydrogen storage properties of $\mathrm{Li}_{3} \mathrm{AlH}_{6} / 2 \mathrm{LiNH}_{2}$ composite. Journal of Alloys and Compounds. 2010;494(12):58-61.

27. Liu Y, Hu J, Wu G, Xiong Z, Chen P. Large Amount of Hydrogen Desorption from the Mixture of $\mathrm{Mg}\left(\mathrm{NH}_{2}\right)_{2}$ and $\mathrm{LiAlH}_{4}$. The Journal of Physical Chemistry C. 2007;111(51):19161-19164.

28. Liu Y, Wang F, Cao Y, Gao M, Pan H. Reversible hydrogenation/ dehydrogenation performances of the $\mathrm{Na}_{2} \mathrm{LiAlH}_{6}-\mathrm{Mg}\left(\mathrm{NH}_{2}\right)_{2}$ system. International Journal of Hydrogen Energy. 2010;35(15):83438349.

29. Liu DM, Fang CH, Zhang QA. Synthesis of the ( $\mathrm{Sr}, \mathrm{Ca})_{2} \mathrm{AlH}_{7}$ hydride. Journal of Alloys and Compounds. 2009;477(1-2):337340 .

30. Izumi F, Ikeda T. A Rietveld-Analysis Program RIETAN-98 and its Applications to Zeolites. Materials Science Forum. 2000;321-324:198-205.

31. Leng HY, Ichikawa T, Hino S, Hanada N, Isobe S, Fujii H. Synthesis and decomposition reactions of metal amides in metal-N-H hydrogen storage system. Journal of Power Sources. 2006;156(2):166-170.

32. Hanada N, Lohstroh W, Fichtner M. Comparison of the Calculated and Experimental Scenarios for Solid-State Reactions Involving $\mathrm{Ca}\left(\mathrm{AlH}_{4}\right)_{2}$. The Journal of Physical Chemistry $C$. 2008;112(1):131-138.

33. Liu DM, Liu QQ, Si TZ, Zhang QA. Synthesis and crystal structure of a novel nitride hydride $\mathrm{Sr}_{2} \mathrm{LiNH}_{2}$. Journal of Alloys and Compounds. 2010;495(1):272-274. 